\title{
Integrating Ideological and Political Education into College English Blended Teaching
}

\author{
Bingyan $\mathrm{Zhu}^{1}$ and Shixiang Liu ${ }^{1, *}$ \\ ${ }^{1}$ School of Intentional Education and Tourism, Hainan College of Software Technology, Qionghai Hainan, 571400, \\ China \\ *Corresponding author. Email: xiangzi0223@126.com
}

\begin{abstract}
In order to integrate ideological and political education into college English teaching, this paper summarizes the status quo of ideological and political education in college English teaching, such as insufficient ideological and political contents in English textbooks, the weak awareness of teachers' ideological and political education, in-comprehensive ideological and political evaluation. Taking the Integrated Skills Course $2^{\text {nd }}$ edition as an example, the blended teaching mode is adopted to integrate Chinese classics, traditional culture, national policies, current affairs and other ideological and political elements into English teaching to realize the implementation of curriculum ideological and political in college English teaching. It's of great significance for students to establish correct outlook on the world, life, and values, spread Chinese culture and enhance cultural confidence.
\end{abstract}

Keywords: Ideological and Political Education; College English; Blended Teaching Mode; cultural

confidence

\section{INTRODUCTION}

Ideological and political education, or moral education is the fundamental task in colleges and universities, and all courses should go in the same direction with ideological and political theory courses for synergistic effect. In December 2016 at the National Conference on ideological and political work in colleges and universities, General Secretary Xi Jinping stressed that we should persist in taking the moral education as the central link, and integrate the ideological and political work throughout the whole process of education so as to achieve full education, allround education and whole process education [1]. In order to implement the spirit of president $\mathrm{Xi}$, college English teachers should be full of the awareness of exploring ideological and political resources in teaching.

The revised College English Teaching Guidelines 2020 proposes that college English is to cultivate students' ability of understanding, interpreting and spreading Chinese culture. Socialist core values should be embedded in college English teaching[2]. It's inevitable for college English teachers to explore ideological and emotional resources in curriculum design, textbook compilation, and teaching implementation. Meanwhile, college English teachers should take advantage of long-standing Chinese excellent traditional cultures and integrate them into classroom teaching, because college English teaching plays an indispensable role in implementing the fundamental task of fostering virtues through education.

\section{THE STATUS QUO OF IDEOLOGICAL AND POLITICAL TEACHING IN COLLEGE ENGLISH}

College English, a compulsory course in colleges and universities, covers a wide range and takes a lot of time for students with different majors to study. The teaching contents of college English are inclusive of the cultivation of humanistic emotions, qualities and ideals apart from knowledge and language skills. It is also one of the main ways to learn western cultures which exert long-term influence on students' values. Owing to the lack of native language culture, it results in the failure of students to express their own native culture in English after years of English learning[3]. Thus, it's necessary to carry out ideological and political education in college English teaching. Currently, the study on ideological and political education in college English is in full swing, but there are still some problems which are embodied in the following aspects.

\subsection{The ideological and political contents are relatively insufficient in college English textbooks.}

At present, the contents of college English textbooks are rich in western cultures, but the significance of Chinese excellent traditional culture has been neglected in college English teaching [4]. Liu Zhengguang and Yue Manman 
point out that most English textbooks narrate European and American culture and society. However, the proportion of Chinese culture reflected in various textbooks is seriously insufficient, which is very unfavorable to cultivating students to tell Chinese stories, spread Chinese culture and establish Chinese cultural self-confidence [5].Yang Jing presents that efforts can be made to explore the integration of ideological and political content and English teaching from multiple angles, and dig deep into the ideological and political elements from the perspective of text theme and text language [6].

\subsection{College English teachers' awareness of moral education are weak, the exploration of moral elements is not deeper.}

Some English teachers hold that it is ideological and political teachers' responsibility to carry out ideological and political education. When in teaching preparation, most English teachers focus on imparting knowledge and skills, and neglect ideological and political education. Liu Zhengguang and Yue Manman propose to raise the teachers' morality awareness, promote their competencies professionally and pedagogically, so that they will be willing and qualified to do the resetting [4].

\subsection{The current teaching evaluation can't give full play the function of ideological and political education.}

Examination content is one of factors that affect the integration of Chinese excellent traditional culture into college English teaching. For a long time, college English evaluation has emphasized result, not integrating Chinese excellent traditional cultures into English exams and tests. Because western culture has long-term influence on students' values, it's important for teachers to take political and ideological into consideration. Teachers should help student correctly to treat western cultural and Chinese culture, reject worshiping foreign cultures, and enhance cultural confidence. Therefore, teachers should improve the proportion of traditional Chinese culture in the range of college examinations. It can effectively motivate teachers and students to teach and learn Chinese culture

\section{THE PRACTICE OF INTEGRATING IDEOLOGICAL AND POLITICAL EDUCATION INTO COLLEGE ENGLISH BLENDED TEACHING}

The teaching innovation of ideological and political education requires that all courses should guide students to establish a correct outlook on the world, life, and values, including public and professional courses. The integrated contents may unconsciously improve students' patriotism and morality.

Taking An Integrated Skills Course 2nd edition for an example, it includes eight units involving the topics of vocational education, environment, fast food, modern communication, gender difference and job hunting. It's significant to make practical research on integrating ideological and political education into college English teaching.

Based on the textbook, the author chooses ideological and political resources, combines language teaching with moral education, and effectively implements the mode of ideological and political blended teaching in College English, which is shown in Figure 1.

Before class, the teacher analyzes the texts and probes deep into the ideological and political elements, uploads related resources to learning platform Xuexitong, which can contribute to tracking students' leaning progress.

In class, students present cultural words such as Word of the Day selected from App Xuexi Qiangguo or China Daily. The teaching methods such as task-based teaching and situational teaching are adopted in classroom teaching. After class, homework is assigned to learning platform Xuexitong, where teacher provides assistance to students. Assessment is indispensable in class and after class. Besides the online automated assessment, multiple assessment includes but not limited to student selfassessment, peer review, inter-group assessment and teacher feedback. 


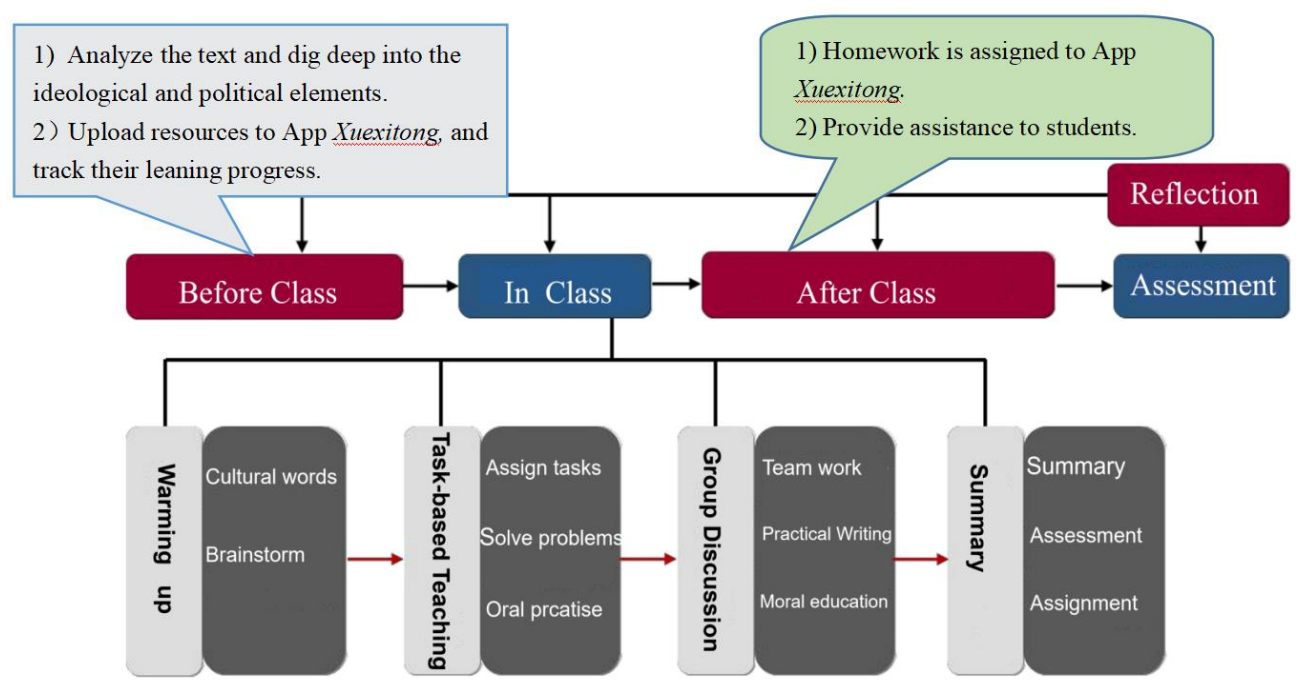

Figure 1. The Mode of Ideological and Political Blended Teaching in College English

\subsection{Analyze the Text and Dig Deep into the Ideological and Political Elements and Choose Ideological and Political resources.}

\subsubsection{Efforts can be made to examine the ideological and political elements that are related to text theme.}

Teachers integrate ideological and political elements into English teaching, such as introducing important national policies and government work reports related to the theme of the unit into college English class in bilingual form. The ideological and political words and sentences which are chosen from the government work reports can arouse students' attention to political issues. For example, the new words purpose, dream are in unit Eight Job-hunting. Before class, teachers search the political words purpose, dream from the English version of the 9th National Congress of the Communist Party of China [7]. For example,

We must observe the Party's fundamental purpose of wholeheartedly serving the people.

... and work tirelessly to realize the Chinese Dream of national rejuvenation.

The study of Ideological and political vocabulary and sentences not only broadens students' knowledge, but also deepens their understanding of current affairs and excellent traditional Chinese cultures, which would benefit students from according closely with the socialist core values embodied in the Chinese dream.

The topic of unit Two is Our Living Environment. When it comes to environmental protection, the teacher should integrate important national policies into teaching. On December 12th, 2020, president Xi made a very important speech at the virtual Climate Ambition Summit. He says that lucid waters and lush mountains are invaluable assets.
It is important to encourage green, low-carbon ways of life and production, and seek development opportunities and impetus from green development. The purpose is to remind students the importance of environmental protection, and take actions to protect our environment.

\subsubsection{Take advantage of current affairs to arouse students' attention, such as the heroic deeds and touching stories of Chinese doctors against COVID-19, cultivate their nation pride and responsibility.}

Nowadays, almost every college student has a smart phone with high interest in current affairs. Combined with the contents of textbook and current affairs, teachers guide students to pay more attention to ideological and political topics and cultivate their correct cognition. For example, In unit Eight Job-hunting, students learn the story of firefighter Tom's dedication to fire fighting in the listening exercise. Students are asked to talk about heroic deeds and touching stories of Chinese doctors fighting against COVID-19 so as to cultivate their nation pride and responsibility. In addition, current affairs such as Every word of the day, President Xi's golden sentences and Chinese aphorisms, which are related to the theme of the unit topics, are shared by students in the classroom teaching. It is of significance to help students understand the domestic and international affairs, guide them to focus ideological and political topics, and learn Chinese excellent traditional culture to cement cultural self-confidence. For example,

Seize the day and live it to the fullest.

只争朝夕，不负韶华。

Happiness is achieved by hard work.

幸福是奋斗出来的。

Only commitment and dedication lead to great achievement. 
功崇惟志，业广惟勤。

Life lies in motion.

生命在于运动。

\subsubsection{Teachers should explore the language features of the text and integrate excellent Chinese culture into class, so students will have a better understanding of cross-cultural communication.}

Chinese excellent traditional cultures are extensive and profound with more than 5000-year-long history. In order to tell Chinese stories well, teachers consciously compare Chinese culture with western culture to improve crosscultural ability based on the contents of the textbook. On the other hand, teachers should select ideological and political contents which both improve students' language skills and morality based on language features of the text. The topic of unit 6 is Generation Gap between a mother and her daughter's view on cleaning the room, which reflects the gap between the two generations, and coming up with the concept of Chinese and Western family education. Based on the facts and their own experience, the teachers lead students to talk about the family education differences between China and Western countries.

Another example, the topic of Unit 3 is about Fast Food. In this unit, the teachers introduce the history of Chinese food culture, lead students to watch the documentary of A Bite of China and compare Chinese and western table manners and dietary culture to improve students' cross-cultural competence.

\subsection{Make full use of online resources such as audio and video materials, useful APPs and other network resources to enrich students' second classroom activities, improve their cultural literacy for better the construction of ideological and political education in English teaching.}

The new media can stimulate learning interests. Nowadays, the development of information technology provides many high-quality resources for ideological and political education. Teachers should make the best use of learning platforms such as Xuexitong, the class of Lan Moyun, Wechat and QQ to forward current affairs, latest news, encouraging stories to students with bilingual forms and so on. Meanwhile, some official accounts, useful App, such as China Daily, Unipus, Xuexi Qiangguo, Hello China, CGTN are recommended to students, and encourage them to know better the government policies, speeches of important leaders and latest news, have access to a lot of ideological and political education materials to enrich students' second classroom activities and speed up the construction of College English in ideological and political education.

\subsection{Ideological and Political Teaching Design of Unit Eight, and Practical Teaching on College English Blended Teaching Integrating Ideological and Political Education.}

Based on English blended teaching mode, teachers explore and segment the ideological and political elements based on the text themes. In this unit, the ideological and political teaching objectives are to 1) cultivate and practice the core socialist values, such as dedication and responsibility in students' job-hunting and future work; 2) bear the traditional Chinese saying only commitment and dedication will lead to great achievement in mind. 3) arouse students' awareness of etiquette in job interview.

Before class, some cultural words or sentences, TED speech are uploaded to Xuextitong, such as, Remain true to our original aspiration and keep our mission firmly in mind (不忘初心, 牢记使命). It educates students to be conscientious in their future jobs and do their own work well.

When finishing the listening excises, students can learn a lesson to be responsible and dedicated person from firefighter Tom. They are asked watch he speech of the fighters fighting against COVID-19, and then discuss THE functions of different jobs in our society with their group members. Teachers summarize what core socialist values have been exemplified, such as dedication and responsibility which should be cultivated and practiced in their job-hunting and future work.

When analyzing the discourse of Text A, which tells the story of Lenny's struggling life in the city where he suffered ups and downs in job hunting and finally settled down, the text encourages the young people to have their own ideals and goals, and try to make their dreams come true. Just as General Secretary Xi Jinping delivered a speech at the centenary of the May the Fourth Movement. $\mathrm{He}$ said that the Chinese youth should always maintain their fine tradition of forging ahead. Meanwhile, he also mentioned that we must remove institutional barriers that block the social mobility of labor and talent and ensure that every one of our people had chance to pursue career through hard work in the report of the 19th National Congress of the Communist Party of China [7].

In oral practice, students are asked to act out the job interview group by group based on the above questions and tips of proper job interview etiquette. It is concluded that China is a state of ceremonies with 5000-year-long history. As the saying goes, etiquette and manners are letters to the four sides of recommendation. It's important for college students to take proper etiquette and manners in job interview.

When writing their resumes, students should clearly know their advantages and disadvantages in job hunting, and they are told the saying who understands the world is learned, 
who understands the self is enlightened (知人者智, 自知 者明也) selected from Tao Te Ching by Lao Tzu.

After class, the movie The Pursuit of Happyness is recommended to watch, just as President Xi said Happiness is achieve by hard-work.

Evaluation is made in class and after class. Besides the online automated assessment, multiple assessment includes but not limited to student self-assessment, peer review, inter-group assessment and teacher feedback.

\section{CONCLUSION}

The ideological and political teaching of college English course is not just a course plus ideological and political education. The key is to master skills how to combine contents of textbook with ideological and political education to inspire students, just as salt is soluble in the water. The online and offline blended teaching mode, which integrates national policies, Chinese excellent traditional culture, current affairs, and other ideological and political elements into the college English teaching, consciously cultivate students' socialist core values, tell Chinese stories well, spread Chinese culture, and enhance cultural self-confidence.

\section{ACKNOWLEDGMENT}

This work has been financially supported by Hainan College of Software Technology 2021 (SZAL2021-13).

\section{REFERENCES}

[1] Xi Jinping. Put the Ideological and Political Work through the Whole Process of Education and Teaching to Create a New Prospect for the Development of Higher Education in China. People's Daily, 2016.12.

[2] The National Ad-ministry Committee on Teaching English Language to Majors in Higher Education. “College English Teaching Guidelines 2020”. Beijing, Higher Education Press, 2020.10.

[3] Han Ling. Four Dimensional path of Ideological and Political Education in Higher Vocational English
Curriculum from the Perspective of Cultural SelfConfidence. Chinese Vocational and Technical Education, 2020, pp. 65-69. DOI:

https://kns.cnki.net/kcms/detail/detail.aspx?dbcode=CJF D\&dbname $=$ CJFDLAST2020 \&filename $=J X C Y 201910$ 011\&uniplatform $=\mathrm{NZKPT} \& \mathrm{v}=\mathrm{XiWq} 8 \mathrm{~B} \% 25 \mathrm{mmd} 2 \mathrm{BJfE}$ cpxCKa2nW\%25mmd2FrufSVCka5zLJXzTa0Fs8khnrc fxQSKqubGRtYWOhYPvK

[4] Chen Xuezhen. "Realization of Ideological and Political Teaching in College English from the Perspective of Optimization Theory". China University Teaching, 2019, pp. 45-48. DOI:

https://kns.cnki.net/kcms/detail/detail.aspx $?$ dbcode $=$ CJF D\&dbname $=$ CJFDLAST2020\&filename $=J X C Y 201910$ 011\&uniplatform $=\mathrm{NZKPT} \& \mathrm{v}=\mathrm{XiWq} 8 \mathrm{~B} \% 25 \mathrm{mmd} 2 \mathrm{BJfE}$ cpxCKa2nW\%25mmd2FrufSVCka5zLJXzTa0Fs8khnrc fxQSKqubGRtYWOhYPvK

[5] Liu Zhengguang \& Yue Manman. Resetting the Educational Philosophy and Restructuring Learning Content to Implement Morality Cultivation in Foreign Language Course Instruction. Journal of Foreign Languages, 2020, pp. 21-28. DOI:

https://kns.cnki.net/kcms/detail/detail.aspx $?$ dbcode $=$ CJF D\&dbname $=$ CJFDLAST2020 \&filename $=$ WYXY20200 $5004 \&$ uniplatform $=$ NZKPT $\& v=Y 4 c A y N f P Q y \% 25 \mathrm{~mm}$ d2BUMXzvwvOCUK4anWuWuOJRo93ZZmVA2Zgq VYXFPoIY34aWmxdGIMAi

[6] Yang Jing. Practical Research of Ideological and Political Education in College English Courses. Technology Enhanced Foreign Languages, 2020, pp. 27-31. DOI:

https://kns.cnki.net/kcms/detail/detail.aspx $?$ dbcode $=$ CJF D\&dbname $=$ CJFDLAST2020 $\&$ filename $=W Y D H 20200$ $4003 \&$ uniplatform $=\mathrm{NZKPT} \& \mathrm{v}=\% 25 \mathrm{mmd} 2 \mathrm{Bz} \% 25 \mathrm{mmd}$ 2FWO7bEuBRa1HxrZi6gR0fL\%25mmd2B3fUYhJGU xfbeJCCwO3vaL4Np2uEMILChAi0YucQ

[7] The 9th National Congress of the Communist Party of China. China Daily, https://language.chinadaily.com.cn/a/201711/06/WS5d0 34782a3103dbf1432840b.html, 2017. 11. 